\title{
Diyabetli Bireyde Postoperatif Dönemde ve Yoğun Bakımda Beslenme Tedavisinin Yönetimi
}

\author{
Postoperative and Intensive Care Management of Nutritional Therapy in Patients with Diabetes
}

\section{Pelin Onar ${ }^{1}$}

Geliş tarihi/Received: 12.01.2019 • Kabul tarihi/Accepted: 25.11.2019

\section{ÖZET}

Diyabet akut ve kronik komplikasyonları olan bir hastalıktır. Toplumda yaygın olarak görülmek ile birlikte, sıklığı gün geçtikçe artmaktadır. Vücudun cerrahi operasyonlara verdiği bazı metabolik yanıtlar nedeni ile ameliyat sonrası dönemde, diyabetik hastalarda sıklıkla hiperglisemi görülmektedir. Hipergliseminin ameliyat sonrası dönemde ve kritik hastalarda morbidite ve mortalite ile yakından ilişkili olduğu bilinmektedir. Hiperglisemiye malnütrisyonun eklenmesi ile birlikte morbidite ve mortalite riski daha da artmaktadır Bu nedenle bu hastalara verilecek olan beslenme desteğinin zamanlaması, içeriği, veriliş yolu çok dikkatli bir şekilde belirlenmelidir. Beslenme desteğinin amacı hipo- ve hiperglisemiden kaçınarak, hastanın ihtiyacı olduğu makro- ve mikro besin ögelerini yeterli ve dengeli bir şekilde hastaya vererek, hedeflenen beslenme durumuna ulaşmaktır.

Anahtar kelimeler: Diyabetik hastalar, beslenme desteği, ameliyat, diyabete özel ürünler

\begin{abstract}
Diabetes is an chronic disease with akut and chronic complications. Diabetes is common, and its frequency is continuously increasing. Due to some metabolic responses of the body to surgical operations, hyperglycemia is frequently seen in diabetic patients in the postoperative period. It is known that hyperglycemia is closely related with morbidity and mortality in the postoperative period and in critical patients. With the addition of malnutrition to hyperglycemia, the risk of morbidity and mortality increases even more. For this reason, the timing, the content, and the administration of the nutritional support must be determined in an extremely careful manner. The objective of nutritional support is to achieve the optimal nutritional status by providing the diabetes patient with the necessary micro- and macronutrients, while still avoiding hypoor hyperglycemia.
\end{abstract}

Keywords: Diabetic patients, nutritional support, operation, diabetes-specific formulas

\section{Gíriş}

Diyabet akut ve kronik komplikasyonları olan bir hastalıktır. Toplumda yaygın olarak görülmek ile birlikte, sıklığı gün geçtikçe artmaktadır. Uluslararası Diyabet Federasyonunun (International Diabetes
Federation [IDF]) verilerine göre Avrupa' da diyabet tanısı almış 59.8 milyar kişi olmak ile birlikte, henüz tanı almamış 23 milyardan fazla kişinin olduğu belirtilmektedir (1). Türkiye Diyabet, Hipertansiyon,

1. İletişim/Correspondence: Selçuk Üniversitesi Tıp Fakültesi Erişkin Hastanesi

Beslenme Destek Ünitesi, Konya, Türkiye

E-posta: pelinonar@yahoo.com • ํㅏ https://orcid.org/0000-0002-9945-1244 
Obezite ve Endokrinolojik Hastalıklar Prevalans Çalışması-II verilerine göre ülkemizdeki diyabet prevalansı \%13.7’ dir (2).

Diyabetik hastalarm \%25-50'sinin hayat boyu en az bir defa cerrahi operasyon geçirdiği bilinmektedir (2). Vücudun cerrahi operasyonlara verdiği bazı metabolik yanıtlar nedeni ile ameliyat sonrası dönemde, diyabetik hastalarda sıklıkla hiperglisemi görülmektedir. Hiperglisemi kritik hastalarda yaygın olarak görülmekte, mortalite ve morbiditeyi arttıran bir risk faktörü olarak kabul edilmektedir. Diyabet tanısı olmayan, hastanede yatan bazı hastalarda da strese bağlı hiperglisemi (SH) gelişebilmektedir (3). Yatan hastalardaki prevalansı \%4-12 olmakla birlikte, bu hastalardan enteral beslenme desteği alanlarda $\% 30$ ve parenteral beslenme desteği alanlarda \%35’tir (1). Hiperglisemi ile ilişkili komplikasyonlar arasında ciddi enfeksiyonlar, miyokard infarktüsü, polinöropati ve çoklu organ yetmezliği bulunmaktadır. Hiperglisemiye malnütrisyonun eklenmesi ile birlikte morbidite ve mortalite riski daha da artmaktadır (1). $\mathrm{Bu}$ derleme yazıda diyabetli bireyde postoperatif dönemde ve yoğun bakımda beslenme tedavisi ilkeleri irdelenecektir.

Hiperglisemi nedeniyle yapılan sıkı glukoz takibi hipoglisemiye neden olmaktadır. Hipoglisemi plazma glukoz düzeyinin $<70 \mathrm{mg} / \mathrm{dL}$, ciddi hipoglisemi plazma glukoz düzeyinin $<40 \quad \mathrm{mg} /$ dL olması olarak tanımlanmaktadır. Beyinin tek enerji kaynağı glukozdur. Bu nedenle uzun süreli hipoglisemi durumunda bilinç kaybı ve hatta ölümler görülmektedir. Normoglycemia in Intensive Care Evaluation-Survival Using Glucose Algorithm Regulation (NICE SUGAR) çalışma verilerinin de dahil edildiği bir meta-analizin yoğun insülin tedavisinin cerrahi yoğun bakımda yatan hastalarda mortaliteyi azalttığı, hipoglisemi görülme sıklığının ise altı kat arttığını gösterdiği bildirilmiştir (2).

Kritik hastalarda 80-110 mg/dL seviyelerindeki plazma glukozu hipoglisemi ve artmış mortalite eğilimi ile ilişkili bulunmuştur (1). Kritik hastalarda önerilen plazma glukoz düzeyi 140-180 mg/dL, koroner arter hastalığı nedeniyle yapılan ameliyatlar sirasında 100-180 mg/dL'dir. Terminal dönemdeki hastalar için daha yüksek glisemi düzeyleri hedeflenebilir. Türkiye Endokrinoloji ve Metabolizma Derneği'nin plazma glukoz düzeyi ölçümünün enteral veya parenteral beslenme desteği alan diyabetli bireylerde 4-6 saatte bir, intravenöz insülin infüzyonu alanlarda ise 1/2-2 saatte bir yapılmasını önerdiği bildirilmektedir (2).

\section{Beslenme Desteği}

Diyabetik hastalara verilecek beslenme desteğinin amacı yeterli beslenme durumunu sağlarken, plazma glukoz düzeylerinin normal sinırlarda tutulması olmalıdır (1).

Kritik hastalarda malnütrisyon prevalansı \%3050 arasında değişmektedir. Yapılan bir çalışmada majör cerrahi geçiren hastaların \%50'sinde malnütrisyon saptanmıştır. $\mathrm{Bu}$ durumun mortalite ve morbidite ile yakından ilişkili olduğu, yara yeri iyileşmesinde gecikme, mekanik ventilatörde kalma ve hastanede yatış süresinde uzamaya neden olduğu gösterilmiştir (4). Bu nedenle yoğun bakımda yatan hastaların beslenme durumlarının saptanması oldukça önemlidir. Kırk sekiz saatten daha fazla yoğun bakımda yatan hastaların malnütrisyon açısından mutlaka taranması gerekmektedir. Tarama testleri arasında kullanımı en kolay ve önerilen test Nütrisyonel Risk Taraması-2002 (NRS-2002)'dir (4-6). Yoğun bakımda 48 saatten daha uzun süre yatan, 5 günden daha uzun süredir mekanik ventilatör desteği alan, çoklu kronik hastalığı olan ve herhangi bir beslenme desteği almayan hastaların malnütrisyon açısından risklidir (5).

Yoğun bakımda yatan hastalarda beslenme durumunu değerlendirmek için kullanılan bazı testler (albümin, prealbümin, antropometrik ölçümler) hastaların ağırlıklarının ölçülememesi ve ani hızlı kas kayıplarının olması nedeni ile uygun değildir (4).

Oral diyet verilen, fakat uzun bir süredir ihtiyacının \%50'sinden daha azını tüketebilen hastalara öncelikle oral beslenme desteği, bu mümkün değil ise; erken (24 saat içinde) enteral beslenme desteği, enteral 
beslenme desteğinin yetersiz veya kontrendike olduğu durumlarda ise parenteral beslenme desteği önerilir. Avrupa Klinik Nütrisyon ve Metabolizma Derneği (European Society for Clinical Nutrition and Metabolism [ESPEN]), 3 gün içerisinde oral yolla beslenmesi beklenmeyen ve enteral beslenmenin kontrendike olduğu veya beslenmeyi tolere edemeyen durumdaki hastalara 24-48 saat içerisinde parenteral beslenme desteği başlanmasını önermektedir. Amerikan Parenteral Enteral Nutrisyon Derneği (American Society for Parenteral Enteral Nutrition [ASPEN]) ise ilk olarak intravenöz (IV) sıvı tedavisinin kullanımını, 7 gün sonra parenteral beslenme desteği başlanması gerektiğini bildirmektedir (4). Aşırı beslemekten kaçınmak için enteral veya parenteral beslenme desteği verilen hastaya planlanan enerji ve protein hedefine 3-7 gün içerisinde çıkılmalıdır (5).

Enteral beslenme verilen hastalarda sürekli besleme bolus beslemeye tercih edilmelidir. Gastrik yoldan besleme, enteral beslenmenin uygun olduğu her hasta için, standart bir uygulama olarak önerilmektedir. Gastrik beslemeyi tolere edemeyen hastalara postpilorik beslenme ve prokinetik ajan kullanımı önerilmektedir. Hastanın aspirasyon riski yüksek ise, özellikle jejunal beslenme uygun olabilir (5).

\section{Enerji İhtiyacının Hesaplanması}

Mekanik ventilatöre bağlı kritik hastaların enerji harcamaları indirekt kalorimetre ile ölçülerek bulunmalıdır.İndirektkalorimetreninkullanılamadığı durumlarda hastanın kullandığı oksijen veya çıkardığı karbondioksit miktarları kullanılarak da hesaplama yapılabilir. Bu parametrelere ulaşılamaz ise; o zaman vücut ağırlığı kullanılarak hesaplanan formüller önerilmektedir (20-25 kkal/kg/gün). Obez hastalarda düzeltilmiş ağırlık kullanılmalıdır. Hastaya yoğun bakıma kabul edildiği ilk hafta hesaplanan enerjinin \%70’inin verilmesi önerilmektedir (5).

\section{Protein İhtiyacinın Hesaplanması}

Kritik hastalar için önerilen protein miktarı 1.3 g/kg/ gün' dür (5).

\section{Glutamin}

Yanık yüzdesinin \%20'den daha fazla olduğu kritik hastalara enteral beslenme başlar başlamaz 10-15 gün boyunca önerilen ilave glutamin miktarı 0.3-0.5 $\mathrm{g} / \mathrm{kg} /$ gün, travma hastaları için 0.2-0.3 g/kg/gündür. Yanık ve travma hastaları hariç diğer yoğun bakım hastalarına enteral glutamin desteği önerilmez. Aynı şekilde, yoğun bakımda yatan, hemodinamik yönden stabil olmayan, özellikle karaciğer ve böbrek fonksiyon bozukluğu olan hastalara IV glutamin verilmesi önerilmez (5).

\section{Karbonhidrat İhtiyacının Hesaplanması}

Hesaplanan enerjinin \%50-60' i karbonhidrattan gelecek şekilde hesaplanmalıdır. Hastaya verilecek günlük maksimum doz kritik hasta için $5 \mathrm{mg} / \mathrm{kg} /$ $\mathrm{dk}$, stabil hasta için $7 \mathrm{mg} / \mathrm{kg} / \mathrm{dk}$ olacak şekilde ayarlanmalıdır (7).

\section{Yağ İhtiyacının Hesaplanması}

Hesaplanan enerjinin \%30-40' i yağdan gelecek şekilde hesaplanmalıdır. Hastaya verilecekgünlük maksimum doz 1g/kg/gün olacak şekilde ayarlanmalıdır (7).

\section{Vitamin, Mineral ve Eser Element Takviyesi}

Günlük verilecek vitamin, mineral ve eser element takviyesi RDA'nın önerdiği dozlar dikkate alınarak yapılmalıdır (7).

\section{Enteral ve Parenteral Beslenmede} Eikosapentaenoik Asit (EPA)/Dokosaheksaenoik Asit (DHA) Önerileri

İçeriğinde nütrisyonel dozda omega-3 olan enteral ürünler yoğun bakım hastalarında kullanılabilirken, bu dozun 3-7 katı olarak tanımlanan yüksek doz omega-3 içeren ürünlerin yoğun bakım hastalarında rutin kullanımı önerilmemektedir. Parenteral beslenme desteği verilen hastalarda EPA + DHA içeren IV lipit emülsiyonları kullanılabilir. Önerilen doz 0.10.2 g/kg/gün'dür (5). 


\section{Enteral Beslenme Desteğine Başlamak için Beklenmesi Gereken Durumlar}

Aşağıdabelirtilen durumlarda enteralbeslenmedesteği başlanması, hastaların enteral beslenmeyi tolere edememesine ve beslenme ile ilgili komplikasyonların (distansiyon, kusma, perforasyon, aspirasyon, ishal, vb.) görülmesine sebep olacağından, bu hastalarda enteral beslenme desteği kontrendikedir.

- Hemodinamik yönden stabil olmayan, doku perfüzyonunda sorun olan şok hastaları,

Yüksek doz $(\geq 0.3 \mu \mathrm{g} / \mathrm{kg} / \mathrm{dk})$ noradrenalin alan şok hastaları enteral beslenmeyi tolere edememekte ve bu hasta grubunda enteral beslenme ürününü aspire etme ve mekanik ventilatör ile ilişkili pnömoni sıklıkla görülmektedir (8).

- Kontrol edilemeyen hipoksik, hiperkapnik veya metabolik asidozu olan hastalar,

- Akut gastrointestinal kanaması nedeni ile gastrointestinal sistem fonksiyonlarinda bozukluk olan hastalar,

- Bağırsak iskemisi olan hastalar,

$\mathrm{Bu}$ hastaların enteral beslenmesi barsak perforasyonuna sebep olabilmektedir.

- Yüksek debili (> $500 \mathrm{~mL} / \mathrm{gün}$ ) intestinal fistülü olan hastalar

- Gastrik rezidüel volümü> $500 \mathrm{~mL} / 6$ saat olan hastalar,

Mide boşalmasında sıkıntı olması nedeni ile bu hastalarda enteral beslenirken distansiyon ve kusma sıklıkla görülmektedir (5).

\section{Refeeding (Yeniden Beslenme) Sendromu}

Ağır malnütrisyonlu hastalarda, uzun süreli açlık sonrasında, beslenmeye başlanması ile ortaya çıkan bir seri metabolik ve biyokimyasal parametrelerin olumsuz etkilendiği bir durumdur. $\mathrm{Bu}$ hastalarda kardiyak, respiratuvar, hematolojik, hepatik, nörolojik ve nöromüsküler sistemde çeşitli komplikasyonlar, hatta ölümler bile görülebilmektedir. Yaygın olarak görülen klinik bulgular; hipokalemi, hipomagnezemi, hipofosfatemi, sodyum ve su retansiyonudur $(9,10)$.

\section{Refeeding Sendromunun Yönetimi;}

- Yüksek riske sahip hastaları belirlenmesi

- 15 günden uzun süren açlık durumu

- Yaşlilık

- \%20 ağırlık kaybı

- Beden kütle indeksinin $<14 \mathrm{~kg} / \mathrm{m}^{2}$ olması

- Yüksek malnütrisyon skoru (NRS 2002 skoru $\geq 3$ )

- Katabolizmaya sebep olan tanılarda verilen agresif beslenme desteği

- Düşük serum potasyum değeri (<3.5 mmol/L)

- Düşük serum magnezyum değeri $\quad<0.75$ $\mathrm{mmol} / \mathrm{L}$ )

- Düşük serum fosfor değeri ( $<0.80 \mathrm{mmol} / \mathrm{L})$

Sıvı dengesindeki sorunların giderilmesi: Hastanın 24 saat içerisinde aldığı ve çıkardığı sıvıların takibinin yapılması ve bu hastalara fazla sıvı yüklenmesinden kaçınılması gerekir (maksimum 20-35 mL/kg/gün).

Elektrolit eksikliklerinin yerine konulması: Refeeding sendromu riski yüksek olan hastaların serum elektrolit konsantrasyonları ilk 72 saat boyunca günlük takip edilmelidir. Eksiklik saptanan hastalara günlük elektrolit replasmanı yapılmalıdır.

Vitamin takviyesi yapılması (özellikle tiamin): Refeeding sendromu riski yüksek olan hastalara ilk 1-5 gün boyunca 200 - $300 \mathrm{mg}$ tiamin desteğine ek olarak; ilk 1-10 gün boyunca multivitamin takviyesi yapılmalıdır.

Eser elementlerin izlenmesi ve eksiklik saptanması durumunda replasman yapılması gerekir. 
Beslenme desteğinin içeriğinin ayarlanması gerekir (9). İlk 3 gün 10-15 kkal/kg/gün enerji verilmelidir. Enerjinin \%40-60'ı karbonhidrattan, \%30-40'ı yağdan ve \%15-20'si proteinden gelmelidir. Üç günden sonra enerji miktarı 15-25 kkal/kg/gün çıkartılıp refeeding

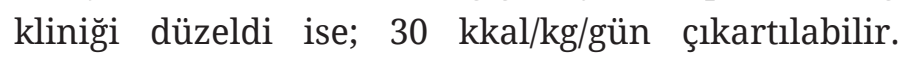
Hedeflenen kaloriye 5-10 gün içerisinde çııılması önerilir (10).

\section{Postoperatif Dönemde Beslenme}

Diyabetik olan ve olmayan hastalarda hiperglisemi kötü klinik sonuçlara sebep olmaktadır. Perioperatif dönemde hiperglisemi diyabetik hastalarda komplikasyonların artmasına sebep olmaktadır. Postoperatif dönemde en sık görülen komplikasyonların başında yara yeri enfeksiyonu ve artmış mortalite gelmektedir. Genel olarak diyabetik hastalarda perioperatif dönemde kan şekerinin hastanede yatan kritik olmayan hastalarda 110-180 mg/dL arasında tutulması önerilmektedir (3).

Hastadaki malnütrisyon varlığı postoperatif dönemdeki komplikasyonları ve mortaliteyi yakından etkilemektedir. Altı ay içerinde \%10-15’ten daha fazla ağırlık kaybı, beden kütle indeksi (BKİ) <18.5 kg/ $\mathrm{m}^{2}$, subjektif global değerlendirmesi: $C$ veya $\mathrm{NRS}>5$ ve preoperatif dönemde albüminin $<30 \mathrm{~g} / \mathrm{L}$ olması postoperatif dönemde komplikasyon görülme riskini arttırmaktadır. Bu nedenle, majör cerrahi geçirecek, orta-ağır malnütrisyonlu hastalarda gerekir ise; operasyonun ertelenmesi ve uygun beslenme desteğine başlanması önerilmektedir. Bazı hasta gruplarında immünonütrisyonun ameliyattan 5-7 gün önce başlatılıp ameliyattan sonra da 5-7 gün daha devam edilmesi önerilmektedir (6).

ESPEN'in 2017 yılında ameliyat olmuş hastalara verilecek beslenme desteğine yer verdiği rehberindeki öneriler şöyle özetlenebilir (6):

- Aspirasyon riski olmayan hastalar anesteziden 2 saat öncesine kadar açık sıvılar alabilir.

- Ameliyattan birkaç saat sonra, herhangi bir komplikasyon düşünülmüyor ise, açık sıvılar tüketilebilir.
- Ameliyat öncesi ve sonrasında mutlaka hastanın beslenme durumu değerlendirilmelidir.

- Perioperatif beslenme desteği malnütrisyon ve beslenme bozukluğu olan hastalarda endikedir. Ayrıca perioperatif dönemde 5 günden daha uzun süre oral alamayacağı düşünülen bireyler ile oral olarak alması gereken besin miktarının \%50' sinden daha azını 7 günden daha uzun süreden beri alamayan hastalara da beslenme desteği yapılmalıdır. On dört günden daha uzun süre yetersiz oral alım yüksek mortalite ile ilişkili bulunmuştur.

- Enerji ihtiyacı 25-30 kkal/kg ve protein ihtiyacı 1.5 g/kg/gün'dür.

- İntestinal tıkanıklık veya ileus, şok, barsak iskemisi, yüksek debili fistüller, gastrointestinal kanama, vb. enteral beslenmenin kontrendike olduğu durumlar dışında, hastaya erken dönemde (ilk 24 saat) enteral beslenme başlanmasının enfeksiyon görülme riskini azalttığı bilinmektedir.

- Oral veya enteral beslenme ile ihtiyacı olan besin ögelerinin 7 gün veya daha uzun süre ile alamayacağı ön görülen hastalarda enteral ve parenteral beslenme kombine verilmelidir. Enteral beslenme mümkün değil ise; 7 günden daha kısa olmamak şartı ile hastaya parenteral beslenme verilebilir.

- Hiperglisemiyi önlemek için yoğun insülin tedavisi yapılmalı, kan glukoz düzeyinin 180 mg/ dl'den yüksek olması durumunda parenteral beslenme içeriğindeki karbonhidrat miktarı azaltılmalıdır.

- Majör kanser cerrahisi geçirecek hastalarda perioperatif veya en azından postoperatif dönemde immünonütrisyon yapılabilir.

- Majör abdominal cerrahi geçirecek malnütrisyonlu kanser hastaları ile yaşlı veya sarkopenik hastalara preoperatif dönemde oral beslenme destek ürünleri verilmelidir. Bu hasta 
grubuna 5-7 gün süre ile immünonütrisyon yapılabilir.

- Perioperatif dönemde 7-14 gün boyunca oral veya enteral yoldan beslenemeyeceği ön görülen hastalara parenteral beslenme verilmelidir.

- Enteral beslenmeye $20 \mathrm{~mL} / \mathrm{sa} / 24$ saat ile başlanıp beslenme hızı yavaş yavaş arttırılıp hedeflenen doza 5-7 gün içerisinde çıkılmalıdır.

\section{Diyabete Özel Enteral Ürünler}

Standart ticari enteral ürünler yüksek karbonhidrat ( \%50) ve düşük veya ortalama lipit (\%30) içerirler ve posalı değillerdir. Bu içerikleri nedeni ile diyabetik hastalarda artmış glisemik ve insülinemik yanıta sebep olabilmektedirler. Bu nedenle diyabetik veya SH'si olan hastalara özel, metabolik kontrolü kolaylaştırmak amacı ile özel ticari ürünler oluşturulmuştur (1).

Genel olarak diyabete özel ürünler düşük glisemik indeksli karbonhidratlar olan hidrolize olmamış nişasta, modifiye maltodekstrin, maltitol veya disakkaritler içerirler. Bazı ürünlerde \%20 oranında fruktoz da bulunmaktadır. Fruktozun kan lipit profili üzerindeki olumsuz etkileri ve insülin direncine neden olmaları nedeni ile geliştirilen yeni nesil ürünlerde fruktoz bulunmamaktadır. Suda çözünen posaların glisemik kontrol üzerindeki olumlu etkileri nedeni ile diyabetik ürünlere eklenmektedirler (1).

Diyabetik ürünler yüksek oranda tekli doymamış yağ asitleri içerirler. Glisemik yanıt üzerinde yüksek yağ içerikli ürünlerin yüksek karbonhidrat içerenlere göre daha olumlu etkilerinin olduğu düşünülmektedir. Protein içerikleri \%15-27 arasında değişiklik göstermektedir. 1500 kkal/gün olacak şekilde verilen diyabetik ürünler önerilen mikro-besin ögelerini karşılamaktadırlar. Yüksek kalitede yeterli kanıt olmamasına rağmen birçok yayın diyabetik veya $\mathrm{SH}$ olan hastalarda bu ürünlerin kullanımını önermektedir. Önerilen en yaygın hasta grubu; mekanik ventilatördeki diyabetik kritik hastalar, evde enetral beslenen diyabetik hastalar, SH'si olan kritik hastalar ve geriatrik hastalardır (1).

\section{SONUÇ VE ÖNERILER}

Diyabet ve SH hastanede yatan hastaların prognozunu kötüleştirmektedir. $\mathrm{Bu}$ hastalara verilecek olan beslenme desteğinin planlanmasının çok iyi yapılması gerekmektedir. Beslenme desteği verilirken; hiper- veya hipoglisemiden, komadan, su ve elektrolit dengesizliklerinden, vb. diğer bazı komplikasyonlardan korunacak şekilde bir beslenme programı oluşturulmalıdır. Hastanın kan glukoz düzeyinin yakından takibi oldukça önemlidir. Diyabetik hastalara özel ürünlerin kullanımını araştıran daha çok klinik çalışmaya ihtiyaç duyulurken; genel kanı kullanılabilir oldukları yönündedir.

Çıkar çatışması - Conflict of interest: Yazarlar çıkar çatışması olmadığını beyan ederler. - The authors declare that they have no conflict of interest.

\section{KAYNAKLAR}

1. Sanz A, Hernandez JA, Ballesteros MD, Botella F, Martínez Olmos MÁ, Olveira G. Evidence-based recommendations and expert concensus on enteral nutrition in the adult patient with diabetes mellitus or hyperglycemia. Nutrition. 2017;41:58-67.

2. Çelik S, Olgun N. Yoğun bakımda hipoglisemi ve hiperglisemi. Yoğun Bakım Hemşireliği Dergisi. 2016;20(1):57-64.

3. Şahin M. Diyabet ve cerrahi. KSU Tip Fak Der. 2015;10(2):87-90.

4. Bayır H, Yıldız İ, Erkuran MK, Koçoğlu H. Yoğun bakım hastalarında malnütrisyon. Abant Medical Journal 2015;4(4):420-7.

5. Singer P, Blaser AR, Berger MM, Alhazzani W, Calder PC, Casaer MP, et al. ESPEN guideline on clinical nutrition in the intensive care unit. Clin Nutr. 2019;38(1):48-79.

6. Weimann A, Braga M, Carli F, Higashiguchi T, Hübner $\mathrm{M}$, Klek S, et al. ESPEN guideline on clinical nutrition in surgery. Clin Nutr 2017;36:623-50.

7. Canada T, Crill C, Guenter P. ASPEN. Parenteral Nutrition Handbook., Silver Spring, Maryland, 2009.

8. Ohbe $H$, Jo $T$, Matsui $H$, Fushimi $K$, Yasunaga $H$. Differences in effect of early enteral nutrition on mortality among ventilated adults with shock requiring low-, medium-, and high-dose noradrenaline: A propensity-matched analysis, Clinical Nutrition, https:// doi.org/10.1016/j.clnu.2019.02.020 
9. Friedli N, Stanga Z, Culkin A, Crook M, Laviano A, Sobotka L, et al. Management and prevention of refeeding syndrome in medical inpatients: An evidencebased and consensus-supported algorithm. Nutrition.
2018;47:13-20.

10. Koçer E, Görmez A. Refeeding (yeniden beslenme) sendromu. Bezmialem Science. 2017;5:121-5. 